\title{
Mud Diapirism on the Gorgan, North Iran
}

\author{
Mehran Arian ${ }^{1 *}$, Ali Sistanipour ${ }^{2}$ \\ ${ }^{1}$ Department of Geology, Science and Research Branch, Islamic Azad University, Tehran, Iran \\ ${ }^{2}$ Department of Geography, Yadegar-e-Imam Khomeini (RAH), Shahr-e-Rey Branch, Islamic Azad University, \\ Tehran, Iran \\ Email: ${ }^{\text {mehranarian@yahoo.com }}$
}

Received 25 May 2015; accepted 22 June 2015; published 25 June 2015

Copyright (C) 2015 by authors and Scientific Research Publishing Inc.

This work is licensed under the Creative Commons Attribution International License (CC BY). http://creativecommons.org/licenses/by/4.0/

cC) (i) Open Access

\begin{abstract}
The several mud volcanoes have been exposed at the Gorgan area in the north Iran. The GarniarigTapeh is the biggest mud volcano and the investigation of its tectonic geomorphology is the main aim in this paper. Also, we have determinated tectonic and geologic setting of Naft-Lije mud volcanoes and several Salses as the exposed mud diapirs at Gorgan on the northern margin of Iran. These mud volcanoes have been formed during quaternary of as a shield shape hill or pool on the flat plain in coastal region SE Caspian Sea. There are flat area and several mud volcanoes that they have been triggered by buoyant driving mechanisms, have been appeared during dormant periods of mud volcanoes activity. This mechanism has been developed in neotectonic regime by convergent setting between The Cimmerian and Eurasian plates. Finally, the main characteristics of the Gorgan area have presented.
\end{abstract}

\section{Keywords}

Garniarig-Tapeh, Mud, Volcano, Gorgan, Iran

\section{Introduction}

Iran country has composed from the several physiographic-tectonic provinces. Each physiographic-tectonic province has a same structural trend and dominant mechanism of deformation, because these have related to tectonic settings, magmatic histories, stratigraphic variations and deformational models of crust. Mud volcanoes have been fund in the some parts of Iran. These parts are very important from the occurrence of petroleum point of view. The most mud volcanoes have been occurred along convergent plate margins where fluid-rich sediment is accumulated in deep-sea trenches at high rates. Such deposits then enter the subduction factory, where liquids and volatiles are released due to increasing compaction stress and temperature.

${ }^{*}$ Corresponding author. 
The mud diapirism is very common in convergent tectonic settings that are marked by compressive forces. As for the first, tectonic activity is an additional trigger to the buoyant driving mechanism. Fluid for mud volcanism is supplied from various sources, including meteoric and volcanic waters, pore water expulsion, hot springs, mineral dehydration reactions, and gas hydrate destabilization [1]. The questions are why and how mud-volcanoes form provokes a lively discussion. Many researchers have worked in different areas and postulated usually a variety of geologic; tectonic; geochemical and hydrogeological reasons.

\section{Materials and Methods}

The high sediment accumulation rate at passive continental margins and the lateral tectonic compression at active continental margins can be consider as the main reasons for space distribution of mud diapirs that formed by density inversion, faulting, fluid migration. In addition, it is obvious that plastic clay layers must be presented for mud volcanoes to form. In some regions, submarine mud volcanoes form in areas characterized by a spatial combination of rapid sediment accumulation and lateral tectonic compression [2].

Characteristics of mud diapirs in the Gorganregion in the northern part of Iran are the main aim in this research. This area is located on convergent tectonic setting between Cimmerian and oceanic part of Eurasian plate (Figure 1).

Previous research on Iran's tectonic setting [4]-[6], salt diapirism [7]-[16], Seismotectonics [17]-[20] have shown that the Zagros belt is the most active zone in Iran [21]-[34]. Alborz belt in north Iran [35]-[66] and Central Iran [67]-[81] have been situated in the next orders. The study area is located on the south Caspian foreland basin.

Dominant structural trend in South Caspian foreland basin province is NW-SE. From tectonics view, it contains the northern foreland basin of West-Central Alborz and lesser Caucasus hinterland in the south margin of Eurasian plate since late Eocene. Although, median part of South Caspian and Black sea basin has uplifted by collision between Eurasian and Cimmerian plates. There are several Mud volcanoes along the coastal part of Gorganarea. The biggest one is Garniarig-Tapeh Mud volcano (Figure 2).

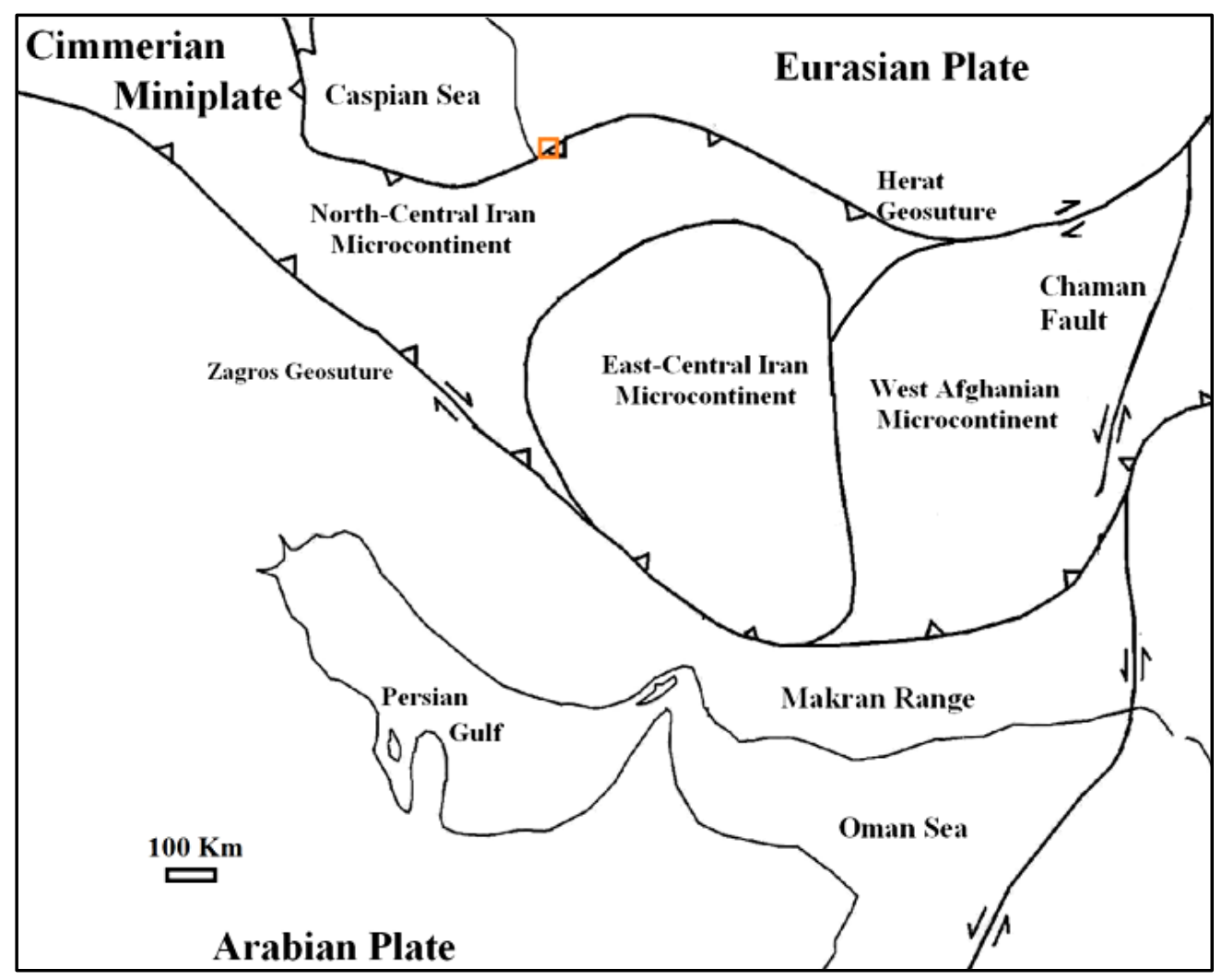

Figure 1. Tectonic framework map of Iran and study area (Red rectangle), modified from [3]. 


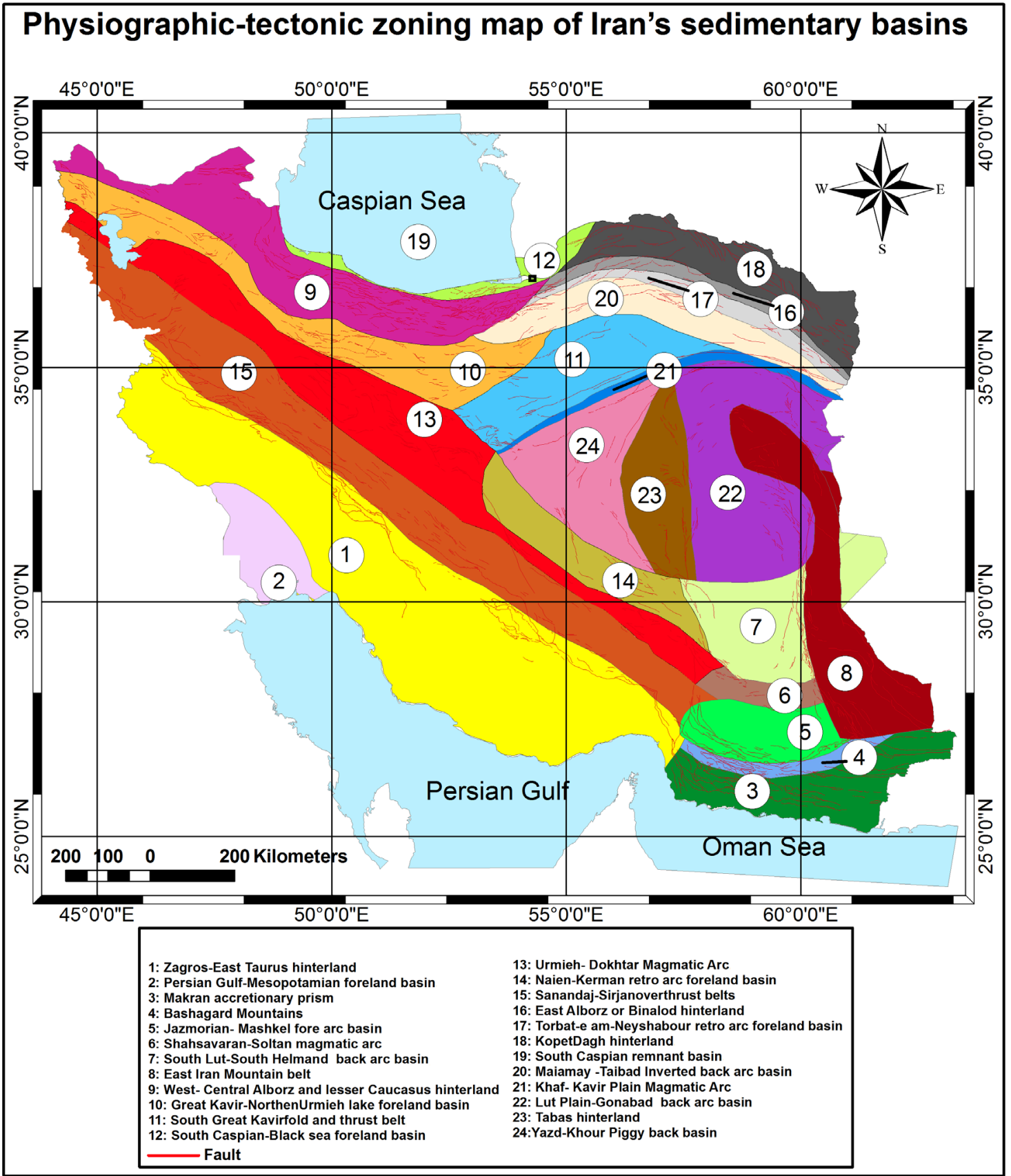

Figure 2. Physiographic-tectonic zoning map of Iran’s sedimentary basins and study area (Black rectangle) modified from [3].

\section{Results and Discussion}

Based on our investigation, the Garniarig-Tapehmud volcano have got a shield shape with near to 25 meters height and near to 650 meters diameter and it has been formed on the flat quaternary plain in coastal region (Figure 3) of Caspian Sea. Also, there are several Salses or small mud craters which they have filled by water (Figure 4 \& Figure 5). These features have been appeared during dormant periods of mud volcanoes.

In central part of the Garniarig-Tapehmud volcano, radial streams have formed in a big pound that it has been filled by viscous clay (Figure 3). Also, there are several mud volcanoes along coastal region Caspian Sea that one of them is Naft-Lije that fund at north of Gomish-Tapehcity (Figure 6). 


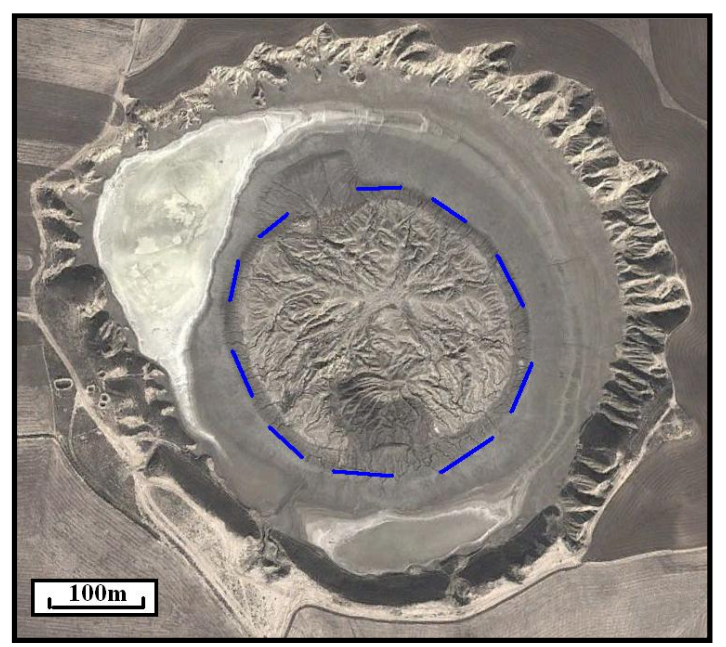

Figure 3. Interpreted ETM+ Satellite image of the Garniarig-Tapeh Mud volcano.
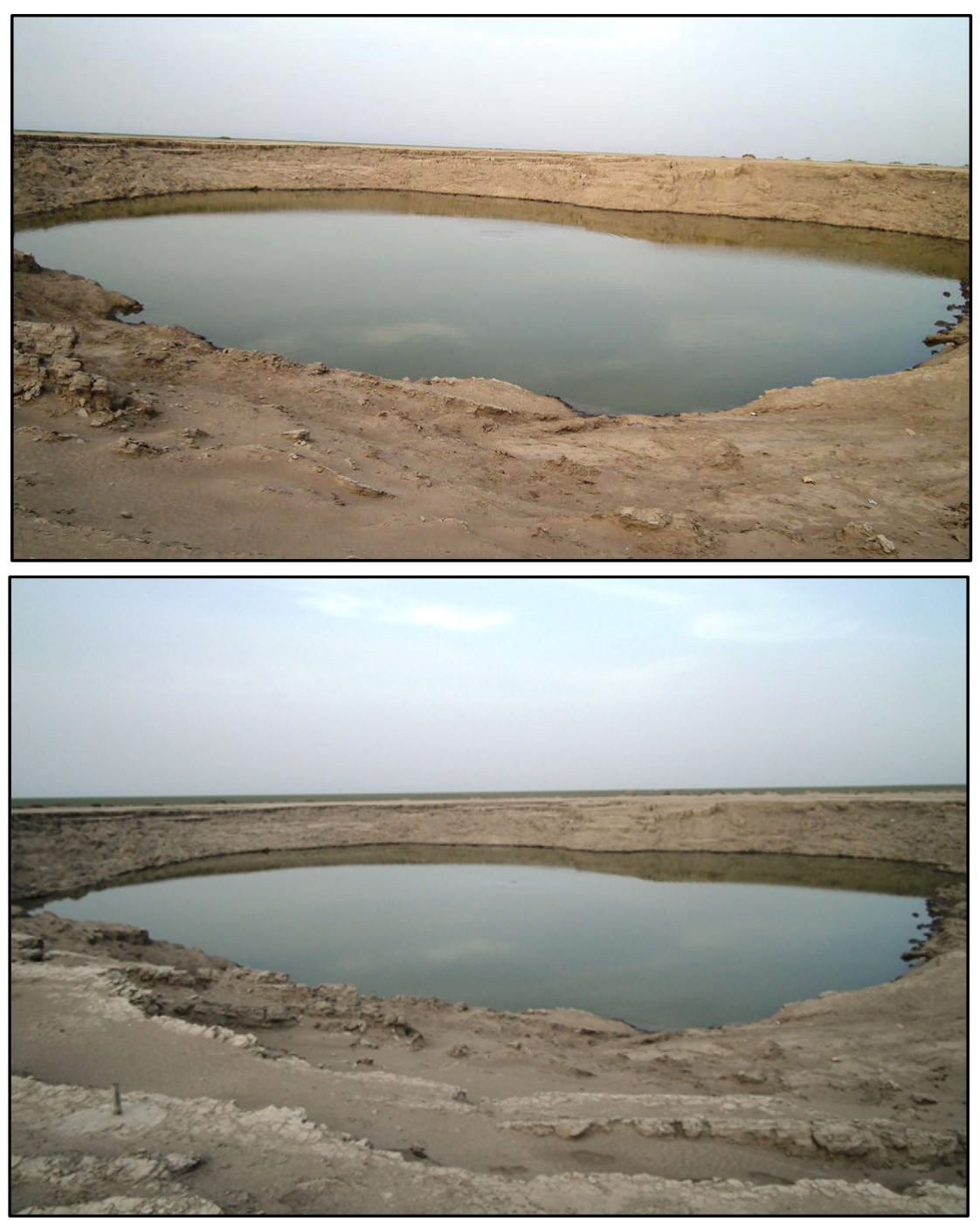

Figure 4. Two views from a salse near to Garniarig-Tapeh mud volcano at north of Gorgan city. 

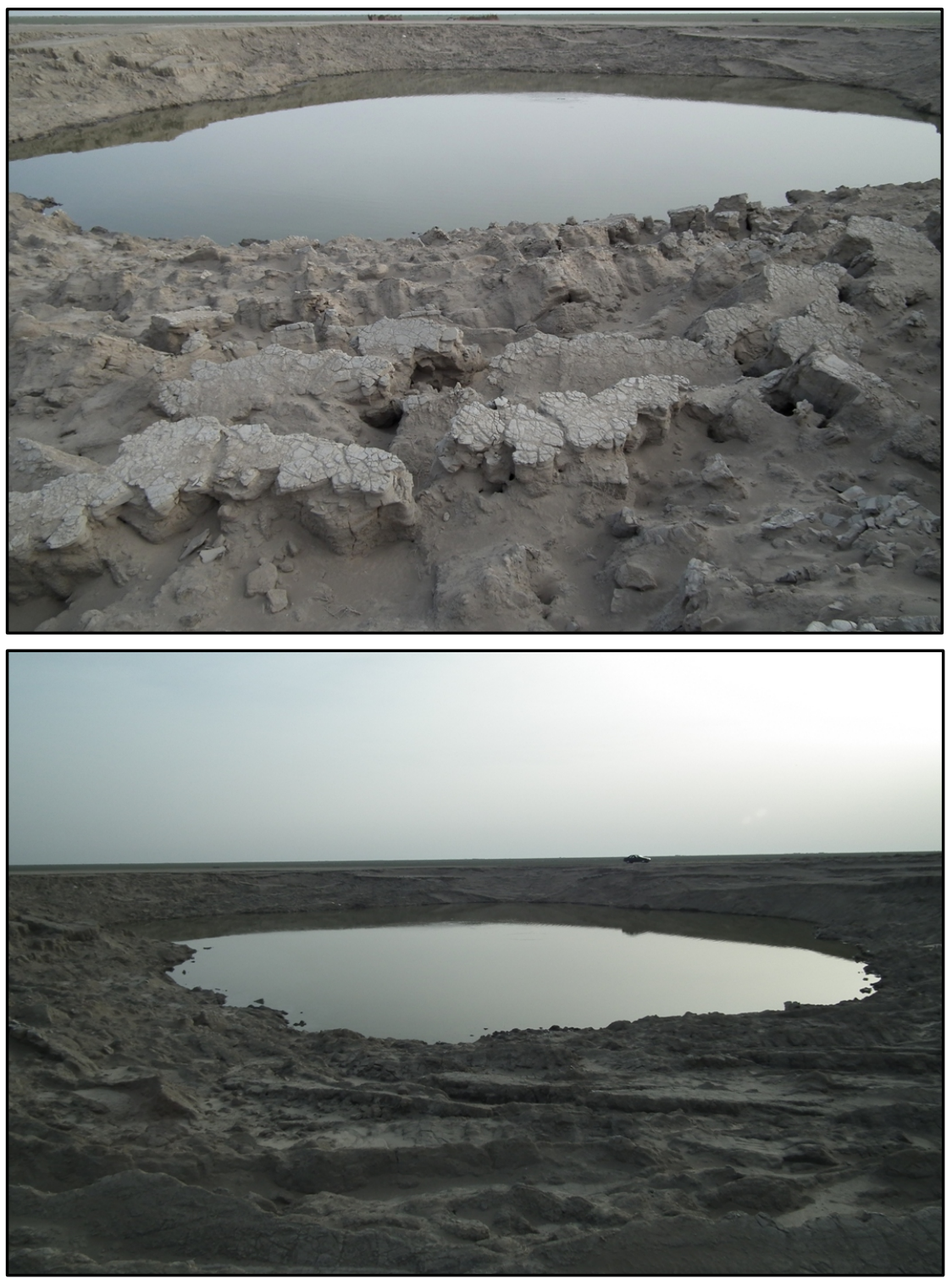

Figure 5. Two views from another salses near to Garniarig-Tapeh mud volcanoat north of Gorgan city.

These mud volcanoes have been triggered by buoyant driving mechanisms, because there are not find geological structures such as folds and faults. This mechanism can be related to neotectonic regime of the south Caspian basin. It means that oceanic lithosphere beneath of the Caspian Sea has been sloped to the south, however it has been covered by thick sediments.

This mud diapirs has been rise from quaternary deposits and probably mud diapirism has been started since Early Pliocene, because it has covered quaternary plain. There are not the index structures in the Gorgan region. It means that mud diapirs have not been triggered by tectonic forces, in contrast of mud diapirism in Makran in the south part of Iran [82]. Also, there are several dispersed mud diapirs, but all of them are the smaller than Garniarig-Tapehdiapir.

\section{Conclusions}

Tectonic geomorphology and origin of the exposed mud volcanoes on the Gorgan area have determinated. Mud diapirism in this zone has not been controlled by only tectonic forces, however there are an old 


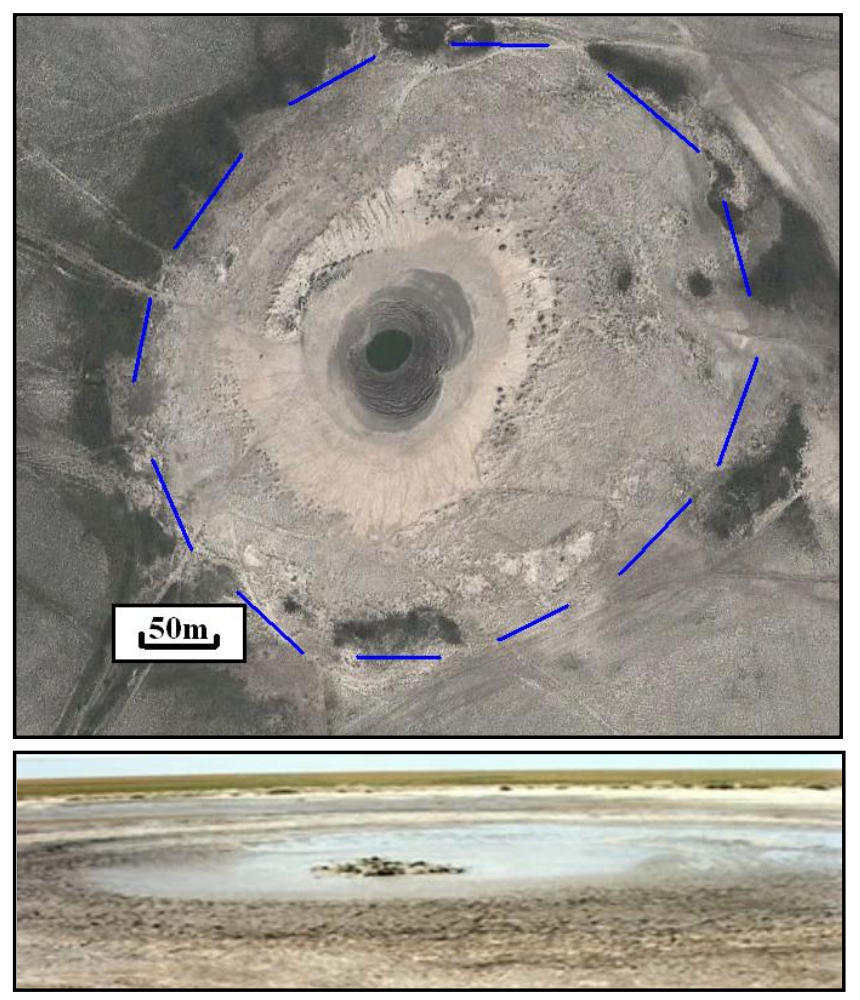

Figure 6. Interpreted ETM + Satellite image (up) and a photo from the center (down) of Naft-Lije mud volcano at North Gorgan.

suture zone between Cimmerian and Eurasian plates.

It means that buoyant driving mechanism is predominant compared with tectonic forces in the coastal parts of the Caspian Sea. Therefore, formation of the new mud volcanoes and more development of the older mud diapirs are not expected for short times. Because mud diapirism has been developed before regional shortening on the old convergent zone between Cimmerian and Eurasian plates. Also, there are several salses that have been appeared during dormant periods of mud volcanoes activity.

\section{Acknowledgements}

This work has funded by the Department of geology, Islamic Azad University, Science and Research branch, Tehran, Iran. Also, Special thanks to Amir Chizari, M.Sc. from Tehran Municipality for preparation of Figure 4 \& Figure 5.

\section{References}

[1] Kopf, A.J. (2002) Significance of Mid Volcanism. Reviews of Geophysics, 40, 52 p. http://dx.doi.org/10.1029/2000RG000093

[2] Milkov, A.V. (2000) Worldwide Distribution of Submarine Mud Volcanoes and Associated Gas Hydrates. Marine Geology, 167, 29-42. http://dx.doi.org/10.1016/S0025-3227(00)00022-0

[3] Arian, M. (2013) Physiographic-Tectonic Zoning of Iran’s Sedimentary Basins. Open Journal of Geology, 3, $169-177$. http://dx.doi.org/10.4236/ojg.2013.33020

[4] Arian, M. (2011) Middle East Tectonics, AsarNafis Press, Qum, 236 p.

[5] Qorashi, M. and Arian, M. (2011) Tectonics of Iran. Geologic Survey of Iran, 336 p.

[6] Arian, M. (2011) Basement Tectonics and Geology of Iran. AsarNafis Press, Qum, 300 p.

[7] Arian, M. (2011) A Preface on Salt Diapirism of Iran. AsarNafis Press, 309 p.

[8] Arian, M. and Noroozpour, H. (2015) The Biggest Salt-Tongue Canopy of Central Iran. Open Journal of Geology, 5, 55-60. http://dx.doi.org/10.4236/ojg.2015.52005 
[9] Asadian, F., Pourkermani, M. and Arian, M. (2007) Tectonic Geomorphology of Salt Structures in the Garmsar-Lasjerd Area. Geographical Research, 39, 75-84.

[10] Pourkermani, M. and Arian, M. (1997) Salt Domes of Central Iran. Journal of Humanities, 3, $29-41$.

[11] Arian, M. (2012) Salt Diapirism and Tectonics. 2nd Edition, AsarNafis Press, Qum, 319 p.

[12] Arian, M. and Noroozpour, H. (2015) Tectonic Geomorphology of Iran’s Salt Structures. Open Journal of Geology, 5, 61-72. http://dx.doi.org/10.4236/ojg.2015.52006

[13] Asadian, F. and Arian, M. (2009) Identification of Diapiric Provinces of Central Iran through Geological and Geographical Analysis. International Journal of Agriculture Environment \& Biotechnology, 2, 3443-3451.

[14] Arian, M. (2012) Clustering of Diapiric Provinces in the Central Iran Basin. Carbonates and Evaporites, 27, 9-18. http://dx.doi.org/10.1007/s13146-011-0079-9

[15] Pourkermani, M. and Arian, M. (1998) Tectonic Geomorphology of Salt Domes in West of Zanjan Province, Iran. Geographical Research, 47, 44-53.

[16] Arian, M. and Feizi, F. (2010) The Significance of Faulting on the Surficial Spreading of Evaporitic Deposits in the Varamin-Semnan Area. Journal of Earth and Resources, 3, 1-20.

[17] Arian, M. and Maleki, R. (2008) Neotectonics. Farazamin Research Center, Tehran, 150.

[18] Pourkermani, M. and Arian, M. (1998) Seismicity of Iran. Shahid Beheshti University Press, Tehran, 212.

[19] Pourkermani, M. and Arian, M. (1997) Seismotectonics. Dez Ab Consulting Engineers Company Press, Tehran, 270.

[20] Arian, M. (2010) Applied Seismotectonics. Farazamin Press, Tehran, 304 p.

[21] Arian, M. and Aram, Z. (2014) Relative Tectonic Activity Classification in the Kermanshah Area, Western Iran. Solid Earth, 5, 1277-1291. http://dx.doi.org/10.5194/se-5-1277-2014

[22] Mashal, M., Kermani, M.P., Charchi, A., Almasian, M. and Arian, M. (2013) Pattern of Structural Geology Underground in Eastern of North Dezfol Embayment. Advances in Environmental Biology, 7, 260-268.

[23] Pazhoohan, M., Arian, M., Ghorashi, M. and Khosrotehrani, K. (2014) A Study of Drainage Pattern Responses to Active Tectonics in Tadvan Region, SW Iran. Geodynamics, 1, 36-41.

[24] Rahimi, N. and Arian, M. (2014) Tectonic Geomorphplogy of Hamedan-Sosangerd Region, West Iran. Advances in Environmental Biology, 8, 119-124.

[25] Arian, M. and Hashemi, A. (2008) Seismotectonic Zoning in the Zagros. Journal of Sciences, 18, 63-76.

[26] Arian, M., Ahmadnia, A., Qorashi, M. and Pourkermani, M. (2002) Structural Analysis of Mengharak Transcurrent Fault System in Zagros, Iran. Special Geo 2002 Conference Issue Geoarabia, 7, 209-210.

[27] Arian, M., Qorashi, M., Pourkermani, M. and Ahmadnia, A. (2003) Fractal Analysis of Mengharak Transcurrent Fault System in Zagros in Iran. 4th International Conference on Seismology and Earthquake Engineering, Tehran, 12-14 May 2003, 23.

[28] Baharvand, S., Pourkermani, M., Ajalloian, R., Arian, M. and Nouryazdan, A.R. (2010) Seymareh Landslide and Its Role in Environmental and Geomorphologic Changes of the Pole-Dokhtar Area. Journal of the Earth, 4, 13-24.

[29] Abdideh, M., Qorashi, M., Rangzan, K. and Arian, M. (2011) Assessment of Relative Active Tectonics Using Morphometric Analysis, Case Study of Dez River (Southwestern, Iran). Geosciences Scientific Quarterly Journal, 20, $33-$ 46.

[30] Arian, M., Qorashi, M., Pourkermani, M. and Ahmadnia, A. (2006) The Structural Significance Kareh Bas Transcurrent Fault System in the Zagros Fold and Thrust Belt. Journal of Geosciences, Geological Survey of Iran, 15, 126-133.

[31] Ehsani, J. and Arian, M. (2015) Quantitative Analysis of Relative Tectonic Activity in the Jarahi-Hendijan Basin Area, Zagros Iran. Geosciences Journal, 19, 1-15. http://dx.doi.org/10.1007/s12303-015-0016-3

[32] Arian, M., Qorashi, M. and Ahmadnia, A. (2003) Analysis of Behbahan Shear Zone. Iranian journal of Geology, 1, 14.

[33] Baratpour, F., Arian, M. and Solgi, A. (2015) Geometric Analysis of Tukak and Kamarun Anticlines on Izeh Zone, Zagros. Geosciences, 24, 191-200.

[34] Arian, M., Ahmadipour, M.R. and Khodaei, K. (2003) The Elements of Fold Style in Soltananticline, Northeast of Pole Dokhtar. Iranian Journal of Geology, 1, 1-8.

[35] Arian, M., Maleki, Z. and Noroozpour, H. (2011) Cenozoic Diastrophism and Deformational Events in the East Central Alborz. Journal of Basic and Applied Scientific Research, 1, 2394-2400.

[36] Feizi, F., Arian, A. and Rahmani, R. (2007) Seismotectonic Zoning in the Eastern Part of the Central Alborz. Journal of Sciences (Islamic Azad University), 17, 151-164.

[37] Khavari, R., Arian, M. and Ghorashi, M. (2009) Neotectonics of the South Central Alborz Drainage Basin, in NW Te- 
hra, N Iran. Journal of Applied Sciences, 9, 4115-4126. http://dx.doi.org/10.3923/jas.2009.4115.4126

[38] Arian, M. and Bagha, N. (2012) Active Tectonics of Tehran Area, Iran. Journal of Basic and Applied Scientific Research, 2, 3805-3819.

[39] Bagha, N., Arian, M., Ghorashi, M., Pourkermani, M., El Hamdouni, R. and Solgi, A. (2014) Evaluation of Relative Tectonic Activity in the Tehran Basin, Central Alborz, Northern Iran. Geomorphology, 213, 66-87. http://dx.doi.org/10.1016/j.geomorph.2013.12.041

[40] Arian, M. and Feizi, F. (2005) Application of Geomorphic Indices to the Assessment of Relative Tectonic Activity Levels in the Alborz-Central Iran Border Zone (from the East of Varamin to the East of Semnan). Journal of Sciences (Islamic Azad University), 15, 378-403.

[41] Arian, M., Bagha, N., Khavari, R., and Noroozpour, H. (2012) Seismic Sources and Neo-Tectonics of Tehran Area (North Iran). Indian Journal of Science and Technology, 5, 2379-2383.

[42] Moghimi, H., Arian, M. and Sorbi, A. (2015) Fault Movement Potential of Marzanabad Area, North Alborz, Iran. Open Journal of Geology, 5, 126-135. http://dx.doi.org/10.4236/ojg.2015.53012

[43] Arian, M. and Pourkermani, M. (2004) Tectonic Elements of South Flank in the East-Central Alborz Mountain. Journal of Sciences, 4, 359-368.

[44] Arian, M. and Qorashi, M. (2006) The Movement Potential Evaluation of the Major Quaternary Faults in Alborz-Central Iran Border Zone, from the East of Tehran to the East of Semnan. Journal of Geosciences, Geological Survey of Iran, 15, 184-188.

[45] Poroohan, N., Pourkermani, M. and Arian, M. (2013) An Assessment of Relationship in F-Parameter and Paleostress Fields in Heterogeneous Lithologies: Roudbar Area (Northwest of Iran). Australian Journal of Basic \& Applied Sciences, 7, 933-942.

[46] Poroohan, N., Poukermani, M. and Aryan, M. (2009) An Assessment on Correlations of Seismotectonic Parameters Preceding and Following Roudbar-Manjil Earthquake (Gilan, North of Iran). Australian Journal of Basic \& Applied Sciences, 3, 2643-2652.

[47] Farrokhnia, A.R., Pirasteh, S., Pourkermani, M. and Arian, M. (2011). Geo-Information Technology for Mass Wasting Hazard Zonation: Central-West Alborz-Iran. Disaster Advances, 4, 24-33.

[48] Khavari, R., Ghorashi, M. and Arian, M. (2009) Assessment of Relative Active Tectonics, South Central Alborz (North Iran). EGU General Assembly Conference Abstracts, 11, 1137.

[49] Sorbi, A., Arian, M. and Pourkermani, M. (2009) The Movement Potential Evaluation of the Major Quaternary Faults in Tehran Quadrangle. Journal of the Earth, 19, 176-182.

[50] Feizi, F. and Arian, M. (2006) The Classification of Thrust Fronts in the Alborz-Central Iran Border Zone from the East of Varamin to the East of Semnan. Journal of Sciences, 16, 75-87.

[51] Arian, M. and Feizi, F. (2005) Application of Geomorphic Indices to the Assessment of Relative Tectonic Activity Levels in the Alborz-Central Iran Border Zone the Alborz-Central Iran Border Zone (from the East of Varamin to the East of Semnan). Journal of Sciences, 15, 378-403.

[52] Arian, M. and Pourkermani, M. (2004) Structural Significance of North Semnan and Attary Faults in Alborz-Central Iran Border Zone. Journal of Sciences (Islamic Azad University), 14, 4551-4569. (In Persian)

[53] Arian, M. and Pourkermani, M. (2005) Cenozoic Diastrophism and Deformational Events in the Southern Flank of Central-East Alborz. Journal of Faculty of Earth Sciences, 10, 43-51.

[54] Arian, M., Pourkermani, M., Qorashi, M. and Ghasemi, M.R. (2003) North Semnan Fault System and Its Role on Basin Division. 8th Symposium of Geological Society of Iran, 2, 11-17.

[55] Pourkermani, M. and Arian, M. (2001) Structural Geomorphology of Northeastern Kurdistan, Sistan and Baluchestan University. Journal of Humanities, 7, 37-48.

[56] Mardani, Z., Ghorashi, M. and Arian, M. (2011) Geomorphic Signatures of Active Tectonics in the Talaghan Rud, Shah Rud and Sefidrud Drainage Basins in Central Alborz, Niran. Geosciences, 20, 159-166.

[57] Sorbi, A., Arian, M. and Pourkermani, M. (2011) The Application of Geomorphic Indices to the Assessment of Relative Tectonic Activity Levels in Tehran Quadrangle. Journal of the Earth, 6, 1-9.

[58] Khavari, R., Ghorashi, M., Arian, M. and Khosrotehrani, K. (2010) Geomorphic Signatures of Active Tectonics in the Karaj Drainage Basin in South Central Alborz, Niran. Geosciences Scientific Quarterly Journal, 19, 67-74.

[59] Mousavi, E.J. and Arian, M. (2015) Tectonic Geomorphology of Atrak River, NE Iran. Open Journal of Geology, 5, 106-114. http://dx.doi.org/10.4236/ojg.2015.53010

[60] Nouri, R., Jafari, M.R., Arian, M., Feizi, F. and Afzal, P. (2013) Correlation between Cu Mineralization and Major Faults Using Multifractal Modelling in the Tarom Area (NW Iran). Geologica Carpathica, 64, 409-416. http://dx.doi.org/10.2478/geoca-2013-0028 
[61] Nouri, R., Jafari, M.R., Arian, M., Feizi, F. and Afzal, P. (2013) Prospection for Copper Mineralization with Contribution of Remote Sensing, Geochemical and Mineralographical Data in Abhar 1:100,000 Sheet, NW Iran. Archives of Mining Sciences, 58, 1071-1084. http://dx.doi.org/10.2478/amsc-2013-0074

[62] Nouri, R., Afzal, P., Arian, M., Jafari, M. and Feizi, F. (2013) Reconnaissance of Copper and Gold Mineralization Using Analytical Hierarchy Process (AHP) in the Rudbar 1: 100,000 Map Sheet, Northwest Iran. Journal of Mining and Metallurgy A: Mining, 49, 9-19.

[63] Arian, M. and Nouri, R. (2015) Lineament Tectonics and Mineralization in Tarom Area, North Iran. Open Journal of Geology, 5, 115-124. http://dx.doi.org/10.4236/ojg.2015.53011

[64] Feizi, F. and Arian, M. (2011) The Role of Structural Controllers in Geneses of Copper Deposits in 1:50,000 Map of Saiin Qaleh. Journal of Sciences, 21, 1-10.

[65] Bahiraee, S., Arian, M., Qorashi, M. and Solgi, M. (2015) The Movement Potential Evaluation of the Mosha Fault ( the West of Firoozkuh to the Shahrestanak). Geosciences, 24, 123-126.

[66] Bagha, N., Ghorashi, M., Arian, M., Pourkermani, M. and Solgi, A.(2015) Neotectonic Analysis of Mosha-North Tehran Fault Zone, Based on Morphotectonic Features, Central Alborz, Northern Iran. Geosciences, 24, 41-52.

[67] Arian, M., Toudeshki, V.H. and Noroozpour, H. (2011) Active Tectonics of Qezel Ozan River Basin, NW Iran. Journal of Applied Environmental and Biological Sciences, 1, 291-295.

[68] Toudeshki, V.H., Pourkermani, M., Arian, M. and Khosrotehrani, K.H. (2011) Influence of Structures on the Ghezel Ozan River. Geosciences, 21, 55-60.

[69] HousiniToudeshki, V. and Arian, M. (2011) Morphotectonic Analysis in the Ghezel Ozan River Basin, NW Iran. Journal of Geography and Geology, 3, 258-260.

[70] Mosavi, E.J. and Arian, M. (2015) Neotectonics of Tabas Area, Central Iran by Index of Active Tectonics (IAT). Open Journal of Geology, 5, 209-223. http://dx.doi.org/10.4236/ojg.2015.54019

[71] Daryani, N.J., Arian, M. and Omran, N.R. (2015) Tectonics and Mineralization of Copper in the Ardestan-Kahang Area, Central Iran by Remote Sensing. Open Journal of Geology, 5, 188-196. http://dx.doi.org/10.4236/ojg.2015.54017

[72] Arian, M. and Pourkermani, M. (2001) Rivers Morphology and Active Tectonic (Reviewing the Current Status of Ghezel Ozon River in the Province of Zanjan). 5th Conference of Geological Society of Iran, Tehran, 28-30 August 2001, 556.

[73] Eshghi, Z., Arian, M. and Pourkermani, M. (2012) Structural Investigation on the Lak Mining Area (Bueen Zahra) Based on Remote Sensing, Used for ITS Mineralization. Journal of the Earth, 6, 145-155.

[74] Arian, M., Toudeshki, V.H. and Noroozpour, H. (2011) Active Tectonics of Qezel Ozan River Basin, NW Iran. Journal of Applied Environmental and Biological Sciences, 1, 291-295.

[75] Alizadeh, H., Arian, M., Lotfi, M., Ghorashi, M. and Ghorbani, M. (2015) Determination of Porphyry Copper Deposit Locations Using Photo Lineament Factor in Northern Parts of the Dehaj-Sardoiyeh Belt. Geosciences, 24, 247-252.

[76] Mosavi, E.J., Arian, M., Ghorashi, M. and Nazemi, M., (2012) Measurements of Geomorphic Indices in Tabas Area. Journal of the Earth, 7, 213-225.

[77] Arian, M. (2010) Earthquake-Fault Hazard Investigations in the Kerman Quadrangle. Journal of Sciences (Islamic Azad University), 19, 176-182.

[78] Arian, M., Pourkermani, M., Sistanipour, A. and Noroozpour, H. (2011) Kinematic Significance of Fold- and FaultRelated Fracture Systems in the Rafsanjan’s Northeast Highlands (Central Iran). Journal of Basic and Applied Scientific Research, 1, 3398-3406.

[79] Arian, M., Pourkermani, M., Sistanipour, A. and Noroozpour, H. (2011) Seismicity and Fault Segmentation of BafqBaghin Fault System (Central Iran). Journal of Applied Environmental and Biological Sciences, 1, 382-396.

[80] Pourkermani, M., Qorashi, M., Arian, M., Sorbi, A., Farokhnia, A. and Solgi, A. (2003) Structural Features in Western Part of the Lut Region. Iranian Journal of Geology, 1, 29-44.

[81] Arian, M., Alizadeh, H. and Noroozpour, H. (2011) Satellite Geometry of Faults and Fractures and Its Relationship with Porphyry Deposits in Northern Parts of Dahaj-Sardoiyeh Belt, South of Iran. Indian Journal of Science and Technology, 4, 1303-1306.

[82] Feizi, F., Arian, M. and Arian, A. (2015) Mud Diapirism on the Makran, Iran: Case Study on the Napag Mud Volcano. Open Journal of Geology, 5, 300-308. http://dx.doi.org/10.4236/ojg.2015.55027 